\title{
Human Adipose Tissue in Culture* V. Studies on the Metabolic Effects of Insulin
}

\author{
U. Smith ${ }^{1}$, S. Boström ${ }^{2}$, R. Johansson ${ }^{2}$ and G. Nyberg ${ }^{1}$ \\ Dept. of Medicine II ${ }^{1}$, Sahlgren's Hospital and Dept. of Zoophysiology ${ }^{2}$, Univ. of Gothenburg, Sweden
}

Summary. Specimens of human adipose tissue were cultured for one week with or without the addition of insulin. The basal as well as the noradrenaline-stimulated lipolysis were enhanced in the explants cultured with insulin, showing that the long-term effect of the hormone is lipolytic. However, an acute antilipolytic effect of insulin could be demonstrated in these explants in the subsequent short-term incubations. The basal rate of glucose incorporation into the lipids was enhanced in the explants cultured with insulin. When insulin was added in the short-term incubations these explants did not further respond to the hormone while this was the case with the explants cultured without insulin. Thus, it seems that prolonged exposure to insulin leads to a diminished acute effect of the hormone on glucose metabolism. However, the same explants responded to the antilipolytic effect showing that insulin was able to bind itself to the membrane. The activities of hexokinase (HK), glucose-6-phosphate dehydrogenase (G6PDH), pyruvate kinase (PK) and lactate dehydrogenase (LDH) were increased in large fat cells both in freshly excised tissue and in the cultured explants. However, the activity of phosphofructokinase (PFK) did not correlate with the cell size. The presence of insulin during the culture period enhanced the activities of G6PDH, PK, and LDH, while this was not found for HK or PFK. The data thus suggest that the metabolic capacity of human fat cells is enhanced by long-term exposure to insulin. Although enzyme induction could be shown for G6PDH, PK and LDH it seems unlikely that this is of importance for the increased rates of glucose metabolism in these explants since the rate-limiting enzymes, HK and PFK, were not increased. Most probably,

* Part of these data were presented at the First International Congress on Obesity in London, England on 9-11 October, 1974. then, this stimulating effect of insulin is exerted on the membrane and the rate of glucose transport.

Key words: Adipose tissue, insulin, catecholamines, glycolytic enzymes, glucose.

Adipose tissue metabolism is generally studied by incubating explants for a few hours in vitro. Under these circumstances host factors may profoundly influence the results. Furthermore, the metabolic effects of prolonged exposure to hormones may not necessarily be the same as those noted after a few hours. With the tissue culture technique it is possible to study the metabolic and morphologic changes of adipose tissue exposed to variations in the biochemical environment for prolonged periods of time. We have previously described a method to maintain explants of human adipose tissue in vitro for several days with intact morphology [1]. The adipocytes are responsive to added insulin and the rates of triglyceride synthesis from glucose and release of glycerol to the incubation medium proceed in a linear fashion for at least one week [2].

Using this method it was recently found that increasing the glucose concentration of the culture medium as well as the addition of insulin enhanced the metabolic capacity of the fat cells in the subsequent short-term incubations [3]. Furthermore, the larger the fat cells the greater the effect of these manipulations. In the present study this finding was further explored by incubating the explants with different concentrations of insulin and the effects on the lipolysis, glucose incorporation and on some key enzymes concerned with glucose metabolism were investigated. The acute effect of insulin on these explants 
was also studied in the subsequent short-term incubations. The results show that insulin may exert antagonistic effects on the lipolytic process; an acute antilipolytic effect and a stimulating effect after longterm exposition. The antecedent biochemical environment also seems to influence the cellular responsiveness to the stimulating effect of insulin on glucose metabolism. Furthermore, insulin was found to increase the activity of some glycolytic enzymes while hexokinase and phosphofructokinase remained unchanged.

\section{Materials and Methods}

Biopsies of subcutaneous adipose tissue were obtained from patients undergoing operations for an abdominal disorder. The ages of the patients varied from 18-76 years and the body weights from 52-130 $\mathrm{kg}$. The patients were operated upon after an overnight fast. Anesthesia was induced with a short-acting barbiturate and maintained with halothane, nitrous oxide and oxygen. The biopsies were usually obtained after the skin incision and immediately placed in a sterile vessel containing medium 199 (Statens Bakteriologiska Laboratorium, Stockholm, Sweden). The culture procedure has been described in detail previously [1]. The incubation medium used was medium 199 containing $5.6 \mathrm{mM}$ glucose unless otherwise specified and with or without the indicated concentrations of insulin (recrystallized pork insulin, Vitrum AB, Stockholm, Sweden). Unless stated the incubations were performed for 1 week at $37^{\circ} \mathrm{C}$. The gas phase was air. Medium was not changed during the incubation period. Thus, insulin was added as a single dose only.

After 1 week the explants were removed from the culture tubes, carefully washed and then either subjected to short-term incubations as previously described [4] or, in the experiments where the enzyme activities were determined, the explants were blotted, weighed and then stored at $-70^{\circ} \mathrm{C}$ until the analyses were performed. After preincubation for $30 \mathrm{~min}$ [5] the short-term incubations were performed for $2 \mathrm{~h}$ in medium 199 containing $1.0 \mathrm{mM}$ glucose, $40 \mathrm{mg} / \mathrm{ml}$ albumin (Bovine albumin, Fraction V, Sigma Chemical Co., St. Louis, Mo.) and with $0.15 \mu \mathrm{Ci}\left[1-{ }^{14} \mathrm{C}\right]$ glucose (New England Nuclear, Boston, Mass., USA) and the indicated concentrations of insulin or noradrenaline (Astra AB, Södertälje, Sweden). Glycerol was determined on the incubation medium as described by Laurell and Tibbling [6].

After the incubation period the tissue lipids were extracted with chloroform-methanol $(2: 1, \mathrm{v} / \mathrm{v})$ as described by Folch et al. [7]. Aliquots of the chloroform phase were evaporated to dryness and $10 \mathrm{ml}$ scintillation fluid $(0.4 \% 2,5$-diphenyloxazole and $0.01 \%$ 1,4-bis-2- (phenyloxazolyl) benzene dissolved in toluene) added. The radioactivity was determined in a Packard Tri-Carb liquid scintillation spectrometer (Packard Instrument Co., Inc., Downers Grove, Ill.).

In the set of experiments where the enzyme activities were evaluated the specimens were prepared immediately after excision. Some of the samples were blotted dry, weighed and the tissue lipids were then extracted as described above and the triglyceride content determined according to Carlson [8]. In this manner the relationship between wet weight and triglyceride content was obtained. When the triglyceride content and the mean cellular weight of a given biopsy, determined as described below, were known the number of fat cells could be calculated.

In agreement with the suggestion of several investigators $[9,10]$ the metabolic parameters studied are expressed on a cellular basis. Mean cell diameter was determined on cells isolated with collagenase (Type I, Sigma Chemical Co., St. Louis, Mo.) as previously described [11].

When the mean cell diameter is known the mean cellular volume can ben calculated as suggested by Goldrick [12]. The mean cellular weight was calculated on the assumption that the density of fat cells is that of triolein [13]. The number of fat cells was then determined by dividing the triglyceride content by the mean cellular weight.

\section{Enzyme Determinations}

Specimens of the adipose tissue were homogenized in 10 volumes ice-chilled $150 \mathrm{mM} \mathrm{KCl}$ containing 50 $\mathrm{mM} \mathrm{KHCO}$ and $6 \mathrm{mM} \mathrm{Na}_{2} \mathrm{H}_{2}$ EDTA [14] using an Ultra-Turrax disintegrator for 75 seconds. The homogenization was performed at intervals in an ice-bath. The homogenates were centrifuged at $2^{\circ} \mathrm{C}$ for $15 \mathrm{~min}$ at $30000 \times \mathrm{g}$ and the supernatant was kept on ice until assayed for enzyme activities.

All enzyme assays were carried out at $23^{\circ} \mathrm{C}$ in a Beckman DB-GT recording spectrophotometer with an automatic positioning attachment at $340 \mathrm{~nm}$. The reactions were started by the addition of an aliquot of the supernatant to the appropriate assay mixture. The assays were performed under conditions where the reaction rate is proportional to the enzyme concentration. All enzyme activities are expressed as $\mu$ moles substrate utilized per min per $10^{6}$ cells.

Hexokinase (E.C.2.7.1.1) was determined according to the method of Bass et al. [15]. For the other enzymes the assay mixtures were:

Glucose-6-Phosphate Dehydrogenase (E.C.1.1. 1.49): $50 \mathrm{mM}$ triethanolamine buffer, $\mathrm{pH} 7.6 ; 5 \mathrm{mM}$ 
Table 1. Effect of different concentrations of insulin during the culture period on the basal lipolysis. The explants were cultured for one week with the indicated concentrations of insulin. The specimens were then washed, preincubated and then incubated for $2 \mathrm{hrs}$ with or without $10^{3} \mu \mathrm{U} / \mathrm{ml}$ insulin as shown. Results \pm SEM of duplicate incubations on specimens from six patients. It should be noted that the patients studied were the same as those shown in Table 3.5 of these explants were cultured with $1.0 \mathrm{mM}$ glucose and one with $5.6 \cdot \mathrm{mM}$

\begin{tabular}{|c|c|c|c|}
\hline \multirow{2}{*}{$\begin{array}{l}\text { Insulin } \\
\text { concentration } \\
\text { during culture } \\
\mu \mathrm{U} / \mathrm{ml}\end{array}$} & \multicolumn{2}{|c|}{$\begin{array}{l}\text { Glycerol release in the } \\
\text { short-term incubations }\end{array}$} & \multirow[t]{2}{*}{ p-level } \\
\hline & $\begin{array}{l}\text { No insulin } \\
\text { nmoles } / 10^{5} \text { cells }\end{array}$ & $\begin{array}{l}\text { Plus insulin } \\
\mathrm{s}\end{array}$ & \\
\hline 0 & $72.6 \pm 17.1$ & $49.3 \pm 11.9$ & $<0.05$ \\
\hline $4 \times 10^{2}$ & $160.6 \pm 48.5$ & $88.9 \pm 21.1$ & $0.05<p<0.1$ \\
\hline $4 \times 10^{3}$ & $122.3 \pm 30.8$ & $82.1 \pm 20.2$ & $<0.05$ \\
\hline $4 \times 10^{4}$ & $112.7 \pm 30.7$ & $80.1 \pm 17.2$ & $0.05<p<0.1$ \\
\hline
\end{tabular}

Table 2. Effect of different concentrations of insulin on the noradrenaline-stimulated lipolysis. The explants were cultured for one week with the indicated concentrations of insulin. The explants were then washed, preincubated and then incubated for 2 hrs with or without the additions of $5 \times 10^{-5} \mathrm{M}$ noradrenaline and $10^{3}$ $\mu \mathrm{U} / \mathrm{ml}$ insulin as shown. Means \pm SEM of incubations on specimens from four patients

\begin{tabular}{|c|c|c|}
\hline \multirow{2}{*}{$\begin{array}{l}\text { Insulin concentration } \\
\text { during culture } \\
\mu \mathrm{U} / \mathrm{ml}\end{array}$} & \multicolumn{2}{|c|}{$\begin{array}{l}\text { Glycerol release in the short-term } \\
\text { incubations }\end{array}$} \\
\hline & $\begin{array}{l}\text { Plus noradrenaline } \\
\text { nmoles } / 10^{5} \text { cells }\end{array}$ & $\begin{array}{l}\text { Plus noradrenaline } \\
\text { and insulin }\end{array}$ \\
\hline 0 & $138.1 \pm 44.9$ & $119.3 \pm 28.0$ \\
\hline $4 \times 10^{2}$ & $252.5 \pm 67.5$ & $250.8 \pm 49.3$ \\
\hline $4 \times 10^{3}$ & $372.9 \pm 53.8$ & $216.7 \pm 16.4$ \\
\hline $4 \times 10^{4}$ & $327.6 \pm 36.1$ & $223.5 \pm 20.4$ \\
\hline
\end{tabular}

EDTA; $10 \mathrm{mM} \mathrm{MgCl}$; $0.5 \mathrm{mM}$ NADP; $1.6 \mathrm{mM}$ glucose-6-phosphate.

Phosphofructokinase (E.C.2.7.1.11): $50 \mathrm{mM}$ triethanolamine buffer, $\mathrm{pH} 7.6 ; 5 \mathrm{mM}$ EDTA; $10 \mathrm{mM}$ $\mathrm{MgCl}_{2} ; 2$ mM cysteine; 0.3 mM NADH; 3 mM ATP; 2 $\mathrm{mM}$ fructose-6-phosphate; $0.6 \mathrm{U}$ aldolase; $0.3 \mathrm{U}$ glycerophosphate dehydrogenase; $0.3 \mathrm{U}$ triosephosphate isomerase.

Pyruvate Kinase (E.C.2.7.1.40): $50 \mathrm{mM}$ triethanolamine buffer, $\mathrm{pH} 7.6 ; 5 \mathrm{mM}$ EDTA; $8 \mathrm{mM}$ $\mathrm{MgCl}_{2} ; 0.15 \mathrm{mM}$ NADH; $2 \mathrm{mM}$ ADP; $1 \mathrm{mM}$ phosphoenolpyruvate; $3.6 \mathrm{U}$ lactate dehydrogenase.

Lactate Dehydrogenase (E.C.1.1.1.27): $50 \mathrm{mM}$ phosphate buffer, $\mathrm{pH} 7.4 ; 0.27 \mathrm{mMNADH} ; 1.33 \mathrm{mM}$ pyruvate.
Table 3. Effect of insulin during the culture period on the metabolism of glucose to triglycerides in the subsequent short-term incubations. The explants were cultured for one week with the indicated concentrations of insulin. The specimens were then washed, preincubated and then incubated for $2 \mathrm{hrs}$ with $\left[1^{-14} \mathrm{C}\right]$ glucose and with or without $10^{3} \mu \mathrm{U} / \mathrm{ml}$ insulin as shown. Results \pm SEM of duplicate incubations on specimens from six patients. N. S. - not significant. It should be noted that the patients studied were the same as those shown in Table 1.5 of these explants were cultured with $1.0 \mathrm{mM}$ glucose and one with $5.6 \mathrm{mM}$.

\begin{tabular}{|c|c|c|c|}
\hline \multirow{2}{*}{$\begin{array}{l}\text { Insulin concentration } \\
\text { during culture } \\
\mu \mathrm{U} / \mathrm{ml}\end{array}$} & \multicolumn{2}{|c|}{$\begin{array}{l}\text { Glucose incorporation in } \\
\text { the short-term incubations }\end{array}$} & \multirow[t]{2}{*}{ p-level } \\
\hline & \multicolumn{2}{|c|}{ nmoles $/ 10^{5}$ cells } & \\
\hline - & $5.7 \pm 0.5$ & $7.8 \pm 1.0$ & $<0.05$ \\
\hline $4 \times 10^{2}$ & $8.4 \pm 1.8$ & $9.1 \pm 1.6$ & N. S. \\
\hline $4 \times 10^{3}$ & $7.2 \pm 0.7$ & $7.8 \pm 1.2$ & N. S. \\
\hline $4 \times 10^{4}$ & $8.5 \pm 0.4$ & $8.0 \pm 1.3$ & N. S. \\
\hline
\end{tabular}

Table 4. Effect of insulin during the culture period on the activities of enzymes involved in glucose metabolism. The explants were cultured for one week with or without addition of $4000 \mu \mathrm{U} / \mathrm{ml}$ insulin. Means \pm SEM of the indicated number of patients. N.S. not significant

\begin{tabular}{llccl}
\hline & \multicolumn{3}{l}{ Culture condition } & \\
\cline { 3 - 4 } Enzyme & & $\begin{array}{l}\text { No insulin } \\
\text { mU/106 cells }\end{array}$ & Plus insulin & p-level \\
& & & \\
\hline HK & $(\mathrm{n}=8)$ & $16.1 \pm 2.2$ & $12.2 \pm 3.1$ & N. S. \\
G6PDH & $(\mathrm{n}=6)$ & $8.3 \pm 1.6$ & $12.0 \pm 3.2$ & $0.05<p<0.1$ \\
PFK & $(\mathrm{n}=11)$ & $107 \pm 21$ & $109 \pm 18$ & N. S. \\
PK & $(\mathrm{n}=7)$ & $469 \pm 136$ & $700 \pm 167$ & $p<0.01$ \\
LDH & $(\mathrm{n}=7)$ & $798 \pm 217$ & $1137 \pm 224$ & $p<0.01$ \\
\hline
\end{tabular}

\section{Results}

\section{Lipolysis}

The explants cultured in the presence of insulin showed a consistently increased basal rate of lipolysis. The release of glycerol was increased even at the lowest concentration of insulin used $(400 \mu \mathrm{U} / \mathrm{ml})$ and a further rise in the insulin concentration did not increase the lipolysis (Table 1). The results are thus in agreement with our previous work [3] and show that the long-term effect of insulin on human adipose tissue is lipolytic. However, when insulin was added in the short-term incubations an acute antilipolytic effect was found (Table 1). 


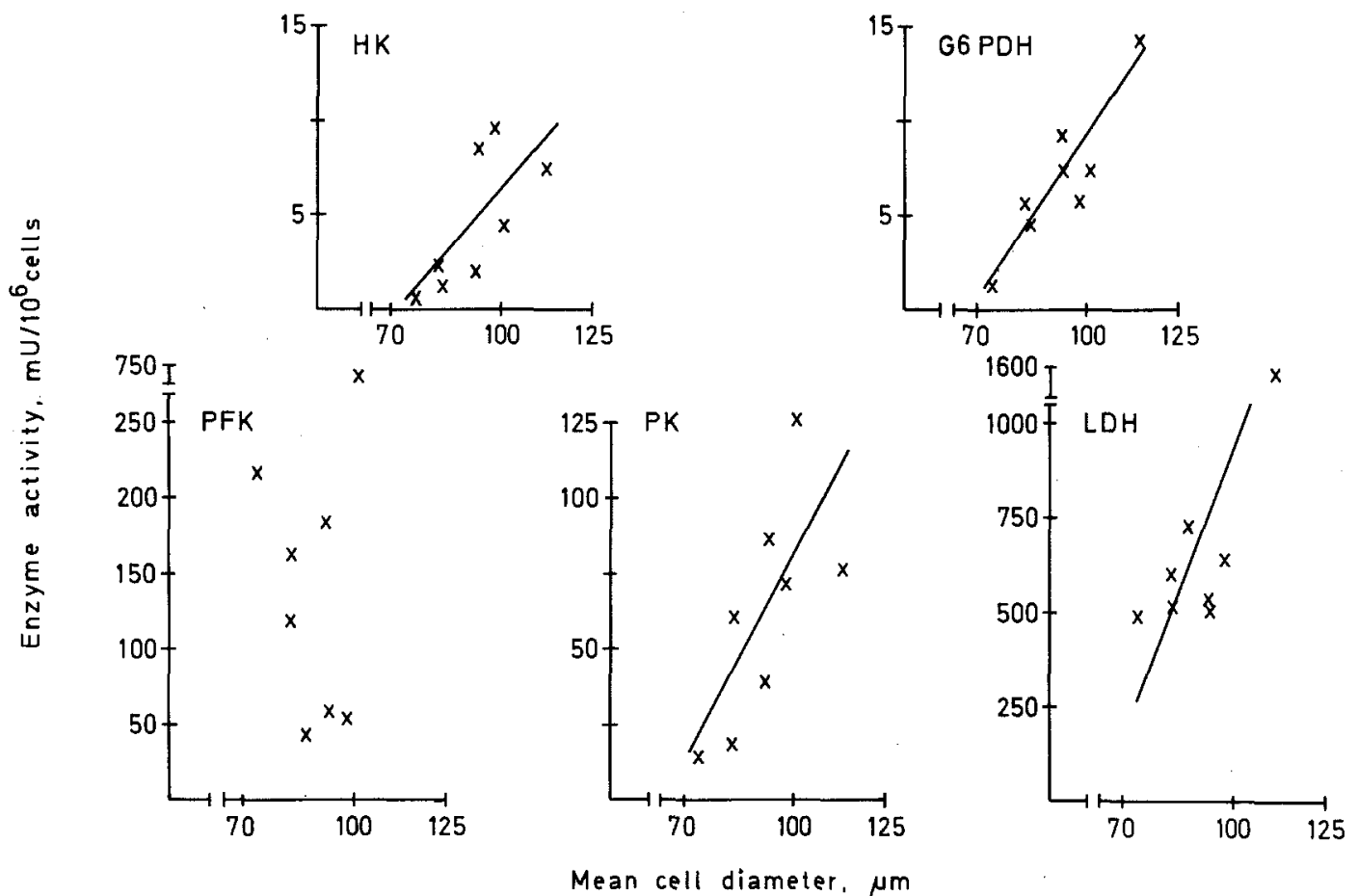

Fig. 1. The correlation between mean fat cell size and the activity of some enzymes concerned with glucose metabolism. Hexokinase $(\mathrm{HK} ; \mathrm{r}=$ $0.72, p<0.05$ ), glucose-6-phosphate-dehydrogenase (G6PDH; $\mathrm{r}=0.90, p<0.01$ ), phosphofructokinase $(\mathrm{PFK} ; \mathrm{r}=0.32, p>0.1)$, pyruvate kinase $(\mathrm{PK} ; \mathrm{r}=0.71, p<0.05)$, lactate dehydrogenase $(\mathrm{LDH} ; \mathrm{r}=0.79, p<0.05)$

In two experiments the explants were removed from the culture tubes, carefully washed and then incubated for another one to two days in the absence of insulin. The lipolytic rate of the explants previously cultured in the presence of insulin decreased successively towards basal values. The experiments thus indicate that the lipolytic effect of insulin may be overcome if the hormone is removed from the culture medium.

The acute lipolytic effect of catecholamine on explants maintained with or without insulin was studied in four experiments (Table 2). The catecholaminestimulated lipolysis was considerably increased in the specimens cultured in the presence of insulin. This effect was not exclusively due to the increased basal rate of lipolysis since the absolute effect of noradrenaline was also enhanced. When insulin was added an acute antilipolytic effect was again noted. In these experiments, however, it was not clearly found for the explants cultured with $400 \mu \mathrm{U} / \mathrm{ml}$ insulin.

\section{Lipid Synthesis from Glucose}

The explants cultured in the presence of insulin had an increased basal rate of glucose incorporation in the short-term incubations (Table 3 ), as also previously found [3]. This effect was pronounced even at the lowest concentration of insulin used $(400 \mu \mathrm{U} / \mathrm{ml})$. When insulin was added in the short-term incubations a significant effect was only found in the explants cultured in the absence of the hormone. It should be noted that the same explants responded to the antilipolytic effect of insulin, as reported in Table 1. Furthermore, the rate of lipid synthesis found in the presence of insulin in the explants previously cultured without the hormone was similar to the basal rate of the explants cultured in the presence of insulin (Table $3)$.

Effects of Cell Size, Glucose and Insulin on Enzymes Concerned in Glucose Metabolism

As shown in Fig. 1 there were significant correlations between mean fat cell size and the activities of hexokinase (HK), glucose-6-phosphate dehydrogenase $(\mathrm{G} 6 \mathrm{PDH})$, pyruvate kinase (PK), and lactate dehydrogenase $(\mathrm{LDH})$ of freshly excised specimens. However, no significant correlation between cell size and the activity of phosphofructokinase (PFK) was found (Fig. 1).

The enzyme activities were also investigated in the explants maintained for one week in vitro. Correlations between mean fat cell size and the activities of HK $(\mathrm{r}=0.66,0.05<p<0.1), \mathrm{G6PDH}(\mathrm{r}=0.99, p<$ 
$0.001)$, PK $(\mathrm{r}=0.87, p<0.01)$ and LDH $(\mathrm{r}=0.78, p$ $<0.05$ ) were found. However, similar to the results obtained with freshly excised specimens, adipocyte size did not correlate with the PFK activity $(\mathrm{r}=0.48$, $p>0.1$ ). Analogous results were obtained with explants cultured in the presence of insulin. With the exception of PK the enzyme activities of freshly excised specimens were similar to those found after maintaining the explants for one week in vitro. The PK activity was about seven times higher in the cultured explants.

When insulin was added during the culture period the G6PDH, PK and LDH activities were increased (Table 4). However, no consistent effect of insulin on the activities of HK or PFK were found. When actinomycin $\mathrm{D}(5 \mu \mathrm{g} / \mathrm{ml})$ was present during the culture period no stimulating effect of insulin on these enzymes was found, indicating that insulin may influence the synthesis of the enzymes. However, the data must be interpreted with some caution since actinomycin D alone lowered the enzyme activities by about $50 \%$.

In seven experiments the effects on PFK, PK and $\mathrm{LDH}$ of increasing the glucose concentration from 1.0 $\mathrm{mM}$ to $5.6 \mathrm{mM}$ or $11.2 \mathrm{mM}$ were studied. For PK and LDH a threefold increase in the activities was noted when the glucose concentration was raised from 1.0 $\mathrm{mM}$ to $5.6 \mathrm{mM}$. No consistent further increase was noted by raising the glucose content from $5.6 \mathrm{mM}$ to $11.2 \mathrm{mM}$. The effect on PFK activity of raising the glucose concentration was slight and only significant when the $1.0 \mathrm{mM}$ and $11.2 \mathrm{mM}$ values were compared (from 57 to $92 \mathrm{mU} / 10^{6}$ cells).

\section{Discussion}

In a previous investigation we have shown that the basal lipolysis of explants cultured for 4 days with the present technique is similar to that found when the specimens were incubated immediately after excision [16]. Furthermore, the effect of catecholamines is enhanced [16] and the basal rate of glucose incorporation is unchanged (unpublished data). This makes it possible to compare directly the metabolic rates of the explants cultured with or without the addition of different hormones.

In the present study it was found that the basal as well as the noradrenaline-stimulated rates of lipolysis were enhanced in the explants cultured with insulin. A pronounced effect was found even at the lowest concentration tested $(400 \mu \mathrm{U} / \mathrm{ml})$. Although insulin was degraded during the culture procedure control experiments have shown that after one week about $50 \%$ of the original concentration $(400 \mu \mathrm{U} / \mathrm{ml})$ was still present in the culture medium. Addition of insulin during the short-term incubations shows the acute antilipolytic effect of the hormone. This effect seemed to be associated with the lipolytic rate, i. e. the higher the basal lipolysis the more pronounced the antilipolytic effect of insulin. Similar results have recently been reported by other investigators in short-term incubations [17].

The reason for these dual effects of insulin on the lipolysis is not clear at present. The acute antilipolytic effect of insulin is presumably mediated by a lowered cyclic AMP level, at least partly due to an enhanced activity of the membrane-bound (low $\mathrm{K}_{\mathrm{M}}$ ) phosphodiesterase $[18,19]$. The lipolytic effect of longterm exposure to insulin may be associated with the enhanced rate of glucose metabolism found in these explants, since a similar effect may be induced by increasing the glucose concentration during the culture period [3]. The fact that glucose or products associated with glucose metabolism, such as the cellular ATP-levels [20], may influence the lipolytic rate has been repeatedly shown [20-25]. A direct effect of insulin on the synthesis of lipolytic enzymes seems also possible.

The increased lipolysis of the explants cultured with insulin is due to a direct effect of the hormone on the metabolism and not to any secondary effects on the fat cell size, as previously discussed [3]. In the present study explants with large mean fat cell sizes were used. We have previously shown that under the experimental conditions used, insulin is unable to increase the size of large fat cells [26].

The observation that prolonged exposure to insulin at the concentrations used increases the basal as well as the catecholamine-stimulated rates of lipid mobilization may be of clinical importance. It has, for instance, been shown that the obese state is associated with hyperinsulinemia $[27,28]$ and increased triglyceride levels $[29,30]$. Apart from an effect of insulin on the lipoprotein synthesis in the liver the present data indicate that chronic exposure to increased insulin levels leads to increased mobilization of lipids from the adipose tissue.

In agreement with a previous study [3] it was found that the explants cultured in the presence of insulin had increased basal rates of triglyceride synthesis from glucose in the subsequent short-term incubations. The fact that the increased cellular rate of metabolism is maintained when the short-term incubations are performed in the same glucose concentration suggests an adaptation of the cellular metabolism either due to an enzyme induction or to a change in the membrane permeability. Although the presence of insulin was found to increase the activity of G6PDH, PK and LDH the activity of HK and PFK, which presumably are the rate-limiting enzymes for the glycolysis [31], 
was not increased. The evidence presently at hand thus suggests that the stimulating long-term effect of insulin on glucose metabolism is mainly due to an effect on the translocation of the hexose across the membrane. The increased activity of G6PDH, PK and $\mathrm{LDH}$ in the presence of insulin may well be secondary to the increased glucose metabolism, since with an increase in the glucose concentration of the culture medium, which also increases cellular glucose metabolism in the short-term incubations [3] exerted a similar effect.

Although it seems from the present data that enzyme adaptation may occur in human adipose tissue, as also suggested by Sjöström [32], this does not seem to be an important regulatory mechanism for a change in the rate of glucose metabolism. The present data are thus in harmony with previous work on human adipose tissue where only small changes in enzyme activities were noted in response to starvation-refeeding experiments [33], a glucose load [31] or to a variation in the feeding pattern [34]. These findings are in sharp contrast to the results with rat adipose tissue, where adaptation of key enzymes may easily be shown $[35,36]$.

With the exception of PK the enzyme activities were similar in freshly excised specimens and in the explants cultured for one week in vitro. The reason for the increased PK levels in the cultured explants is unclear but may be associated with the levels of lactate [37]. The observation that large fat cells have increased activity of some glycolytic enzymes is in general agreement with the studies of Englhardt et al. [38]. It was suggested in that work that this may partly be due to enzyme adaptation as also indicated by the present study.

It was found in the present study that explants cultured in the absence of insulin responded significantly to the effect of this hormone on glucose metabolism in the short-term incubations. The basal rate of glucose conversion was increased to a similar extent in the explants cultured in the presence of insulin. However, no further increase was found by the addition of the hormone in the short-term incubations. In interpreting these results it is essential to exclude the possibility that, in spite of the precaution taken (washing and preincubation for $30 \mathrm{~min}$ ), insulin was present in the interstitial space. However, we have previously shown that the increased rate of glucose metabolism found in the explants cultured in the presence of insulin could not be blocked by the addition of insulin antibodies [3]. Furthermore, the fact that the same specimens responded to the antilipolytic effect of insulin indicates that the hormone was able to bind itself to the membrane. Thus, it seems valid to conclude that the prolonged exposure to these concentrations of insulin may influence the cellular responsiveness to the hormone. This finding may be relevant for the fact that large fat cells from subjects with obesity and hyperinsulinemia [27, 28] exhibit a diminished responsiveness to insulin in vitro [10] as well as in vivo [39]. At least for the adipose tissue it may well be, as also suggested by Grey and Kipnis [40], that the diminished acute effect of insulin represents an adaptive phenomenon which is secondary to the hyperinsulinemia. It has indeed been shown that the presence of insulin during the culture of human lymphocytes leads to a diminished number of insulin receptors [41]. Whether a similar feedback mechanism exists for human fat cells is presently unknown but may well be the case. Although the fact that explants cultured in the presence of insulin responded to the antilipolytic effect of the hormone would argue against this concept, it is possible that the insulin receptors mediating the effect on glucose metabolism are different from those mediating the antilipolytic effect [42].

Acknowledgements. This study was supported by grants from the Swedish Medical Research Council (project B76-13X-3506) and the Tore Nilsson Fund. The excellent technical assistance of Mrs C. Goldmarck and Mrs U. Carlbrand is gratefully acknowledged.

\section{References}

1. Smith, U.: Morphologic studies of human subcutaneous adipose tissue in vitro. Anat. Rec. 169, 97-104 (1971)

2. Smith, U.: Studies of human adipose tissue in culture. I. Incorporation of glucose and release of glycerol. Anat. Rec. 172, 597-602 (1972)

3. Smith, U.: Studies of human adipose tissue in culture. III. Influence of insulin and medium glucose concentration on cellular metabolism. J. clin. Invest. 53, 91-98 (1974)

4. Smith, U.: Insulin responsiveness and lipid synthesis in human fat cells of different sizes: Effect of the incubation medium. Biochim. biophys. Acta (Amst.) 218, 417-423 (1970)

5. Östman, J.: A procedure for in vitro studies on fatty acid metabolism by human subcutaneous adipose tissue. Acta med. scand. 177, 183-197 (1965)

6. Laurell, S., Tibbling, G.: An enzymatic fluorimetric micromethod for the determination of glycerol. Clin. chim. Acta 13, 317-322 (1966)

7. Folch, J., Lees, M., Sloane Stanley, G. H.: A simple method for the isolation and purification of total lipides from animal tissues. J. biol. Chem. 226, 497-509 (1957)

8. Carlson, L. A.: Determination of serum glycerides. Acta Soc. Med. upsalien. 64, 208-213 (1959)

9. Björntorp, P.: Studies on adipose tissue from obese patients with or without diabetes mellitus. II. Basal and insulin-stimulated glucose metabolism. Acta med. scand. 179, 229-234 (1966)

10. Salans, L. B., Knittle, J. L., Hirsch, J.: The role of adipose cell size and adipose tissue insulin sensitivity in the carbohydrate intolerance of human obesity. J. clin. Invest. 47, 153-165 (1968) 
11. Smith, U., Sjöström, L., Björntorp, P.: Comparison of two methods for determining human adipose cell size. J. Lipid Res. 13, 822-824 (1972)

12. Goldrick, R. B.: Morphological changes in the adipocyte during fat deposition and mobilization. Amer. J. Physiol. 212, 777-782 (1967)

13. Hirsch, J., Gallian, E.: Methods for the determination of adipose cell size in man and animals. J. Lipid Res. 9, 110-119 (1968)

14. Shonk, C., Boxer, E.: Enzyme patterns in human tissues. I. Methods for the determination of glycolytic enzymes. Cancer Res. 24, 709-721 (1964)

15. Bass, A., Bridiczka, D., Eyer, P., Hofer, S., Pette, D.: Metabolic differentiation of distinet muscle types at the level of enzymatic organization. Europ. J. Biochem. 10, 198-206 (1969)

16. Smith, U., Isaksson, O., Nyberg, G., Sjöström, L.: Human adipose tissue in culture. IV. Evidence for the formation of a hormone antagonist by catecholamines. Europ. J. clin. Invest. 6, 35 (1976)

17. Lisch, H.-J., Sailer, S., Sandhofer, F., Tschikof, R., Braunsteiner, H.: The action of insulin and glucose on lipolysis in isolated human fat cells. Horm. Metab. Res. 6, 25-30 (1974)

18. Manganiello, V., Vaughan, M.: An effect of insulin on cyclic adenosine $3^{\prime}: 5^{\prime}$-monophosphate phosphodiesterase activity in fat cells. J. biol. Chem. 248, 7164-7170 (1973)

19. Zinman, B., Hollenberg, C. H.: Effect of insulin and lipolytic agents on rat adipocyte low $\mathrm{Km}$ cyclic adenosine $3^{\prime}: 5^{\prime}$-monophosphate phosphodiesterase. J. biol. Chem. 249, 2182-2187 (1974)

20. Ho, R. J.: Dependence of hormone-stimulated lipolysis on ATP and cyclic AMP levels in fat cells. Horm. Metab. Res. Suppl. 2, 83-87 (1970)

21. Carlson, L. A.: Inhibition of the mobilization of free fatty acids from adipose tissue. Ann. N. Y. Acad. Sci. 131, 119-142 (1965)

22. Chlouverakis, C.: The lipolytic action of fructose-1-6-diphosphate. Metabolism 17, 708-716 (1968)

23. Hall, C. L., Ball, E. G.: Factors affecting lipolysis rates in rat adipose tissue. Biochim. biophys. Acta (Amst.) 210, 209-220 (1970)

24. Smith, U.: Effects of glucose and insulin on lipolysis rates in human fat cells of different sizes. FEBS Letters 11, 8-10 (1970)

25. Efendić, S., Östman, J.: Catecholamines and metabolism of human adipose tissue. IV. Influence of glucose on catecholamine induced lipolysis in human omental adipose tissue in vitro. Acta med. scand. 187, 485-491 (1970)

26. Smith, U., Jacobsson, B.: Studies of human adipose tissue in culture. II. Effects of insulin and medium glucose on lipolysis and cell size. Anat. Rec. 176, 181-184 (1973)

27. Björntorp, P., Berchtold, P., Tibblin, G.: Insulin secretion in relation to adipose tissue in man. Diabetes 20, 65-70 (1971)

28. Stern, J. S., Batchelor, B. R., Hollander, N., Cohn, C. K., Hirsch, J.: Adipose-cell size and immunoreactive insulin levels in obese and normal-weight adults. Lancet 1972 II, 948-951
29. Sims, E. A. H., Goldman, R. F., Gluck, C. M., Horton, E. S., Kelleher, Ph. C., Rose, D. W.: Experimental obesity in man. Trans. Ass. Amer. Phycns 81, 153-170 (1968)

30. Olefsky, J., Reaven, G. M., Farquhar, J. W.: Effects of weight reduction on obesity. Studies of lipid and carbohydrate metabolism in normal and hyperlipoproteinemic subjects. J. clin. Invest. 53, 64-76 (1974)

31. Galton, D. J., Wilson, J. P. D.: The effect of starvation and diabetes on glycolytic enzymes in human adipose tissue. Clin: Sci. 41, 545-553 (1971)

32. Sjöström, L.: Adult human adipose tissue cellularity and metabolism with special reference to obesity and fatty acid synthesis de novo. Acta med. scand. Suppl. 544, 1-52 (1972)

33. Shrago, E., Glennon, J. A., Gordon, E. S.: Studies on enzyme concentration and adaptation in human liver and adipose tissue. J. clin. Endocr. 27, 679-685 (1967)

34. Bray, G. A.: Lipogenesis in human adipose tissue. Some effects of nibbling and gorging. J. clin. Invest. 51, 537-548 (1972)

35. Hansen, R. J., Pilkis, S. J., Krahl, M. E.: Effect of insulin on the synthesis in vitro of hexokinase in rat epididymal adipose tissue. Endocrinology 86, 75-65 (1970)

36. Weber, G.: Integrative action of insulin at the molecular level. Israel J. med. Sci. 8, 325-340 (1972)

37. Simon, L., Robin, E.: Relative anaerobic glycolytic capacity and pyrovate kinase activity of rabbit tissues. Int. J. Biochem. 3, 329-332 (1972)

38. Englhardt, A., Gries, F. A., Liebermeister, H., Jahnke, K.: Size, lipid and enzyme content of isolated human adipocytes in relation to nutritional size. Diabetologia 7, 51-58 (1971)

39. Rabinovitz, D., Zierler, K. L.: Forearm metabolism in obesity and its response to intraarterial insulin. Characterization of insulin resistance and evidence for adaptive hyperinsulinism. $\mathbf{J}$. clin. Invest. 41, 2173-2181 (1962)

40. Grey, N., Kipnis, D.: Effect of diet composition on the hyperinsulinemia of obesity. New Engl. J. Med. 285, 827-831 (1971)

41. Gavin, J. R., Roth, J., Neville, D. M., De Meyts, P., Duell, D. N.: Insulin-dependent regulation of insulin receptor concentrations: A direct demonstration in cell culture. Proc. nat. Acad. Sci. (Wash.) 71, 84-88 (1974)

42. Jerums, G., Galton, D. J.: Two types of insulin receptors mediating opposite effects on cyclic-AMP in fat cells of the rat. Horm. Metab. Res. 6, 241-243 (1974)

Received: November 3, 1975 and in revised form: January 23, 1976

Dr. U. Smith

Dept. of Medicine II

Univ. of Gothenburg

Sahlgren's Hospital

S-41345 Gothenburg

Sweden 